\title{
THE APPLICATION OF SCIENTIFIC APPROACH IN TEACHING READING COMPREHENSION FOR THE TENTH GRADE STUDENTS OF SMA PABA BINJAI
}

AN ARTICLE

Submitted in Partial Fulfillment of the Requirements for the Degree of Sarjana Pendidikan

By:

SONIA NURUL FADHILAH

Registration Number: 2161121045

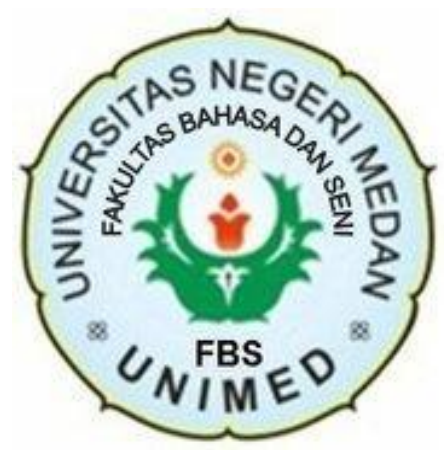

ENGLISH AND LITERATURE DEPARTMENT

FACULTY OF LANGUAGES AND ARTS

STATE UNIVERSITY OF MEDAN 


\title{
THE APPLICATION OF SCIENTIFIC APPROACH IN TEACHING READING COMPREHENSION FOR THE TENTH GRADE \\ STUDENTS OF SMA PABA BINJAI
}

*Sonia Nurul Fadhilah

**Siti Aisah Ginting

\begin{abstract}
This study was aimed to analyzing how the teacher apply the scientific approach in teaching reading comprehension for the tenth grade students of SMA PABA Binjai and to find out the difficulties faced by the English teacher in teaching learning process using scientific approach in 2013 curriculum. This study was conducted by using descriptive qualitative research design. The data sources of the research were the English teacher of SMA PABA Binjai. The techniques of collecting data were observation and interview. The findings showed that there was only one step of Scientific Approaches used in teaching process. Afterward, that was three difficulties faced by the teacher related to the application of 2013 Curriculum; (a) teacher faced difficulties in student's readiness. Students were not actively participated in the classroom; (b) teacher faced difficulties in the assessment, (c) teacher faced difficulties in the steps of Scientific Approach could not apply in one meeting. The teacher was not able to manage the time when using the scientific approach. All teachers must be prepared by the government by giving them some teaching practice and training related to the application of 2013 Curriculum.
\end{abstract}

Keywords: Scientific Approach, Teaching Reading Comprehension, 2013 Curriculum.

\footnotetext{
*Graduate Status

** Lecturer Status
} 


\section{INTRODUCTION}

\section{Background of Study}

Curriculum is a basis of teaching and learning process. It is also one of the educational resources that give positive contribution to the students' development. Thus, every teaching and learning process has to follow the curriculum. Richards (2001) as cited in Ardiansah (2016) defines curriculum as something that includes the processes that are used to determine the needs of a group of learners, to develop aims or objectives for program to address those needs, to determine appropriate syllabus, course structure, methods, and teaching materials, and to carry out an evaluation of the language program that results from these processes.

Nowadays, Indonesia has been applied the 2013 Curriculum as a revision of the previous curriculum, School Based Curriculum (KTSP). 2013 curriculum is a curriculum of value which is occupied by character building. Mulyasa (2013) argues that 2013 curriculum is aimed to produce human resources that are productive, creative, innovative, and affective through the strengthening of attitude, skill and knowledge.

In Curriculum 2013, Minister of Education published an approach. Approach is another factor which supports in language teaching. Language teaching and learning process is conducted by apply teaching approach. There is an approach of language teaching in Indonesia that is suggested by Curriculum 2013 which is called as scientific approach. 
Scientific Approach is scientific process to acquire knowledge systematically based on physical evidence. According to Musfiqon and Nurdyansyah (2015), scientific approach is the basic concept that inspires the teaching methods by applying scientific characteristics. In the teaching and learning process through scientific approach, the teacher is only as a facilitator while the students are the center during the teaching and learning process. The students are demanded to search more informations by their own ways. Scientific Approach in 2013 Curriculum consists of five steps, they are observing, questioning, experimenting, associating, and communicating. These steps are applied when teachers teach the students in the classroom.

The application of scientific approach in learning English covers four main skills, one of the skills is reading. Reading is very important skill that the students must be mastered, because the reading cannot be separated in the process of teaching and learning. In accordance with this fact, students must have a good comprehension in understanding the reading text in order to get the information and the meaning of the text.

According to Wolley (2011) reading comprehension is a very complex cognitive activity and the process of making meaning from the text. Teacher also has an important role in developing students' understanding in reading text. That is why teaching reading is not easy because the teachers do not only ask the students to read the text but also they have to think how the students can comprehend all the aspects of reading in it. 
Based on the observation, SMA PABA Binjai is one of more than Senior High School which applies the 2013 curriculum using Scientific Approach. From the analysis, the teacher didn't give significant contribution toward the teaching and learning process. This phenomenon was proved when the teacher applied the way of teaching and learning process in the classroom. The teacher still used conventional way, for instance: explaining, copying, giving exercise, and asking questions. These activities were monotonous and not interesting which have been all conducted in the classroom, and also the students less independent because they only depend on the teachers and they did not dare to express their ideas and opinions. It can be seen when researcher interviewed the teacher.

Besides, from the analysis of lesson plan that the teacher used in the classroom, the teacher has not regularly used a scientific approach so that the teacher was still not good enough in applying questioning to the students. Supposedly, the students ask the questions not teacher who gives questions. In this activity, the teacher is more active compared to the students.

Based on the description, the researcher needs to find out the details and application of the scientific approach of 2013 curriculum and the difficulties faced by the teacher in applying this approach at SMA PABA Binjai. Considering these problems, the researcher decides to conduct a research entitled The Application of Scientific Approach in Teaching Reading Comprehension for The Tenth Grade Students of SMA PABA Binjai. 


\section{REVIEW OF RELATED LITERATURE}

\section{Theoretical Framework}

According to Thomas and Berlin (2014: 3) curriculum is a general of overall plan of the content or specific studies in school that should be offered to the student by qualifying him for graduation, certification or for entrance into professional or a vocational. Meiyana (2010) defines curriculum as a plan or program for all the experiences which the learner encounters under the direction of the school. In practice, the curriculum consist a number of plans, in a written form and of varying scope, which delineate the desired learning experiences.

In accordance with Kemendikbud (2013), 2013 Curriculum is competency and character based on curriculum. 2013 curriculum was born as a response to the various criticisms of School Based Curriculum 2006. It is in accordance with the development need and the world of work. 2013 Curriculum is one of the government's efforts to resolve the various problems being faced by the world of education today. 2013 Curriculum improves mindset, strengthens governance curriculum, deepens, and expands the material, reinforces learning, and adjusts learning load in order to ensure compatibility between what is desirable to what produced (Permendikbud, 2013: 81A).

Scientific approach is defined as the process of finding out information in science, which involves testing the ideas by performing experiments and making decisions based on the results of analysis (Longman, 2014). Musfiqon and Nurdyansyah (2015) say that scientific approach is the basic concept that inspires of 
teaching methods by applying scientific characteristics. The application of scientific approach in learning not only focused on how to develop the competence of learners in observing or experiments, but also how to develop knowledge and thinking skills so that it can support creative activity in innovating.

Woolley (2011: 33) states that reading comprehension is the process of making meaning from the text and a very complex cognitive activity. Yale (2008) states comprehension is making sense out of the text. According to Oakhill, Cain and Elbro (2014:1) reading comprehension is a complex task, which requires the orchestration of many different cognitive skills and abilities.

\section{Conceptual Framework}

In Scientific Approach, the main teaching process resource is teacher. That means, the teachers are expected to be a facilitator of learning process according to 2013 Curriculum. The steps of Scientific Approach are observing, questioning, experimenting, associating, and communicating. In observing process, the students can be invited to explore on the object to be studied. They use this step to increase students' curiosity. Then in questioning process, the students solve their confusion in the observing process. It helps them to complete information and give them more opportunity to be active. Then in experimenting process, the students should find as much information from internet or other resources. Then in associating process, the students are required to try to analyze what is learned. The teacher asks the students to work in group to discuss for understand content of the material. And the last is 
communicating. In communicating process, the students should communicate what they have learned. They deliver the result of their observation, the conclusion which they have got from the deep analysis.

Even though, in reality not all English teachers of Senior High School apply this approach in teaching reading comprehension. Some of the teachers do not understand this approach. To solve the problem, the aim of this research is to give the teacher the information about scientific approach in teaching reading comprehension process. This study conducted by using a descriptive qualitative method. Therefore, to find out the answer of the problems of this research, it could be used by observing, interview, and documentation.

This research intended to analyze the application of scientific approach and to find out the difficulties faced by the teacher in applying scientific approach in teaching reading comprehension for the tenth grade students of SMA PABA Binjai.

Finally, the findings will be expected to be useful for the English teacher while teaching in the English classroom. As the end of this research, hopefully this thesis will help the English teacher of SMA PABA Binjai in teaching reading comprehension process as the relevant studies and references to comprehend this approach in English learning. 


\section{RESEARCH METHODOLOGY}

This research was conducted by using descriptive qualitative method. Creswell (2014:32) said that in qualitative research is an approach for exploring and understanding the meaning individuals or groups ascribe to a social or human problem. The process of research involves emerging questions and procedures, data typically collected in the participant's setting, data analysis inductively building from particulars to general themes and the researcher making interpretations of the meaning of the data.

In this research used interview guide, observation sheet, and document to collect the data. Therefore, researcher got the data source from one English teacher who teaches reading comprehension in the tenth grade students of SMA PABA Binjai.

\section{Techniques of Analysis Data}

\section{Data Condensation}

a. Selecting means the way to choose the best or most suitable data. In the process of selecting, the data were collected from transcripts of video recording teaching learning process and interviewing teacher to get suitable data.

b. Focusing means to pay particular attention to suitable data. In the process of focusing, the suitable data will be in teacher questions.

c. Simplifying means to make the data simpler or easier to understand.

d. Abstracting means to consider the data of the teacher theoretically. 
e. Transforming means to make a through or dramatic change in the form and appearance.

\section{Data Display}

After data condensation, the next step in analyzing the data is the data display. It is the process of displaying data in the form of table or essay. Data display is an organized assembly of information that permits conclusion is drawing and action taking. Miles, Huberman, and Saldana (2014) state that looking at displays help use to understand what is happening and to do something further analysis or caution on that understanding. In this study, the researcher used essay and table in displaying the data. The researcher takes the data from the application of scientific approach in teaching reading comprehension and also presents the data from the teacher and students toward the application of scientific approach in teaching reading comprehension.

\section{Drawing Conclusion/Verifying}

Conclusion involve stepping back consider what the analyzed data mean and to access their applications for the questions at hands. Verification integrally linked to the drawing conclusion, revising the data as many times as necessary to verify this emergent conclusion. Conclusions are drawn to answer the research questions by describing and interpreting what the researcher sees in the data. The researcher examined all the data and findings. Then, the researcher made the conclusion. 


\section{RESEARCH FINDINGS AND DISCUSSION}

\section{Research Findings}

The findings showed that there was only one step of Scientific Approaches used in teaching process. The first meeting, the teacher used the observing process. Based on the observation of the learning process in the classroom, it can be found that, the teacher in observing process gave the students information about the topic discussion used LCD and power point. While, in the second meeting the teacher only used the process of experimenting. Based on the observation in the second meeting, it can be found that, in experimenting process, the teacher facilitated the students to try to gather as much information about material that being studied. The teacher and the students found and collected the information from the internet. Both meetings, the teacher had not applied the five steps of the Scientific Approach in teaching reading comprehension.

Then based on the data interview, it was found that the difficulties faced by the teacher in applying scientific approach in teaching reading comprehension was on the student's readiness. Students were not actively participated in the classroom. The teacher explained that the students did not want to ask questions, they tended to be silent. Then, the assessments were more complicated. The teacher explained that if the sum of the class was too much, the assessment would take many times and the assessment should observe the students one by one. And last, the steps of Scientific Approach could not apply in one meeting. The teacher was not able to manage the time when using the scientific approach. 


\section{Discussion}

The result of the research questions presents in the research findings and the data are discussed in the discussion. It discussed the findings of the two research questions. The research questions are: How is the application of scientific approach in teaching reading comprehension for the tenth grade students of SMA PABA Binjai and What are the difficulties faced by the teacher in applying scientific approach in teaching reading comprehension for the tenth grade students of SMA PABA Binjai.

The researcher conducted the observation in the classroom for two meetings at X-MIA 1 on Tuesday, October 6th 2020 until Tuesday, November 3rd 2020 and the material is descriptive text. Based on Permendikbud 81A (2013), the steps of learning by using scientific approach are observing, questioning, experimenting, associating, and communicating. The researcher found that the teacher used one step of scientific approach in teaching reading comprehension. Such as in the first meeting, the teacher only used the observing process. The teacher in observing process gave the students information about the topic discussion used LCD and power point. Then, the second meeting, the teacher only used the process of experimenting. Based on the observation in the second meeting, in experimenting process, the teacher facilitated the students to try to gather as much information about material that being studied. The teacher and the students found and collected the information from the internet. 
There were three steps of scientific approach that the teacher didn't use such as, questioning, associating, and communicating. The discussions of both problems of research were elaborated by the researcher with some relevant studies as follows:

According to Pahlevi (2013), Permendikbud 81A classify the steps of learning by using scientific approach such as observing, questioning, experimenting, associating, and communicating. Furthermore, Pahlevi found that the teacher did not apply the questioning and associating was less effective. The student's responses to questioning and associating show that they could not learn well due to the less creativity of the teacher. It was supported from the data analysis, according to Zaim (2017), also found that the teachers were not able to implement the observing and questioning steps optimally yet. Based on the English teachers' opinion, the implementation of 2013 curriculum seemed to be in a rush. Teachers were not ready to implement the scientific approach in 2013 curriculum.

Based on the data analysis, in fact, there were three steps of scientific approach were not applied by the teacher. The teacher didn't apply questioning on each meeting. The teacher did not stimulate the student's curiosity and the students were not feeling motivated. The teacher was more active compared to the students. The teacher should give the students stimulation by giving them some attaractive questions to build curiosity. However, this way only worked to the active students. Then, the teacher also didn't apply associating on each meeting. The teacher only gave the exercises with individual, not make a work in group to discuss for understand content of the material. And last, this communicating process was not 
applied in the second meeting by the teacher in teaching reading comprehension because the students would need extra hours to prepare assignments which were given by the teacher. Then, the teacher did not invite the students to present the answers of the questions in reading descriptive text that was learned in the classroom.

This is also supported from the interview of the English teacher on Tuesday, November 17th 2020 in the office teacher of SMA PABA Binjai. From the data analysis, it was found that the difficulties faced by the teacher in applying scientific approach in teaching reading comprehension was on the student's readiness. Students were not actively participated in the classroom. The teacher explained that the students did not want to ask questions, they tended to be silent.

Based on the research of Exley (2005), he characterized Indonesian students as passive, shy, and quiet. Furthermore, Astuti (2013) also stated that most of the students were lack of motivation because they don't have friends to talk. Because of that, the assessments were more complicated and the steps of Scientific Approach could not apply in one meeting. Intan and Didi (2017) also stated that the teacher had difficulties to get students follow the directions and the activities. The teacher expected everyone participating in activity. While in fact, some students had difficulties in following the teacher pace. It makes the teacher unable to manage the time when using the Scientific Approach.

Based on the explanation above, it can be concluded that the application of scientific approach in teaching reading comprehension is appropriate to be used in the 
learning. However, the teacher should apply all activities and steps in the scientific approach. Moreover, the teacher should always be more active and creative in applying all the steps in the learning process.

\section{CONCLUSIONS AND SUGGESTIONS}

\section{Conclusions}

Based on the analysis of the data, the teacher had not applied the five steps of the Scientific Approach in both meetings of teaching reading comprehension. The finding showed that there was only one step of Scientific Approaches used in teaching process. The first meeting, the teacher used the observing process. Then, in the second meeting, the teacher used the process of experimenting.

Based on the analysis of the data, it was found that the difficulties faced by the teacher in applying scientific approach in teaching reading comprehension was on the student's readiness. Students were not actively participated in the classroom. Then the assessments were more complicated and last the steps of Scientific Approach could not apply in one meeting. The teacher was not able to manage the time when using the scientific approach.

\section{Suggestions}

Considering the importance of this study, there are two suggestions which are expected to be meaningful for English teacher and next researcher. For the English teacher, the teacher should know the concept of Scientific Approach and be able to 
apply all the five process of Scientific Approach in teaching reading process. Then, for the next researchers the finding of the research can be used as a reference to other researchers to conduct varied research and further studies in other school or classroom which will be a very useful reference to the teacher and students in teaching and learning process. 


\section{REFERENCES}

Ashar, Irmawati. 2016. The Implementation of the 2013 Curriculum of English at SMKN 1 Bantaeng: An Evaluative Study. Vol 3. Januari 2016. International Journal of English Education.

Cresswell, J.W. (2014). Research Design: Qualitative, Quantitative, and Mixed Methods Approaches. Lincoln: University of Nebraska.

Daryanto. 2014. Pendekatan Pembelajaran Saintifik Kurikulum 2013. Yogyakarta: Gava Media.

De Boer, John J. and Martha Dalmann. 1964. The Teaching of Reading. New York: Holt, Rinehart and Winston.

Ekawati, Y. N. 2017. English Teacher's Problems in Applying the 2013 Curriculum. Vol 6. December 2017. Journal of English Education.

Permendikbud. 2013. Peraturan Menteri Pendidikan dan Kebudayaan Republik Indonesia No. 81A Tahun 2013 Tentang Implementasi Kurikulum. Jakarta.

Ruhimat, Toto. 2011. Kurikulum \& Pembelajaran. Jakarta: Rajagrafindo Persada.

Sani, R, A. 2014. Pembelajaran Saintifik untuk Implementasi Kurikulum 2013. Jakarta.

Wallace, Cathrine. 1996. Reading. New York: Oxford University Press.

Williams, Eddie. 1999. Reading in the Language Classroom. London: Phoenix FLT.

Zaim, M. 2017. Implementing Scientific Approach to Teach English at Senior High School in Indonesia. Vol 13. January 2017. Journal of Asian Social Science. 